\title{
Inter-Professional High Fidelity Simulation: The Way Forward for End-of-Life Care Education
}

"Corresponding author

Priscilla Cunningham, BSc (Hons), RGN School of Nursing and Midwifery

Queen's University Belfast

Belfast, Northern Ireland

E-mail: pcunningham22@qub.ac.uk

Volume 3 : Issue 1

Article Ref. \#: 1000PMHCOJ3120

\section{Article History}

Received: April $17^{\text {th }}, 2017$

Accepted: June $13^{\text {th }}, 2017$

Published: June $28^{\text {th }}, 2017$

\section{Citation}

Cunningham P, Reid J, Noble H, et al. Inter-professional high fidelity simulation: The way forward for end-of-life care education. Palliat Med Hosp Care Open J. 2017; 3(1): 6-10. doi: 10.17140/PMHCOJ-3-120

\section{Copyright}

(C2017 Cunningham P. This is an open access article distributed under the Creative Commons Attribution 4.0 International License (CC BY 4.0), which permits unrestricted use, distribution, and reproduction in any medium, provided the original work is properly cited.
Priscilla Cunningham, BSc (Hons), RGN ${ }^{1 *}$; Joanne Reid, RN, PhD, MSc, PGCE, BSc ${ }^{1}$; Helen Noble, PhD, BSc (Hons), PG Cert. Academic Practice, DMS, RN'1; Helen McAneney, MSci, PhD²; Claire Carswell'; Susan McClement, PhD, MN, BScN, RN³; Billiejoan Rice, BSc (Hons), MSc, RGN ${ }^{1}$; Andrew Spence, MB, MSc, MRCP4; Ian Walsh, MD, MSc, FRCS (Glasg) FRCSI FRCS (Urol) ${ }^{5}$; Claire Lewis, RN, PhD, PGCE, BSc, Dip ${ }^{6}$

${ }^{1}$ School of Nursing and Midwifery, Queen's University Belfast, Belfast, Northern Ireland ${ }^{2}$ Centre for Public Health, School of Medicine Dentistry and Biomedical Sciences, Queen's University Belfast, Belfast, Northern Ireland

${ }^{3}$ College of Nursing, Rady Faculty of Health Sciences, University of Manitoba, Canada

${ }^{4}$ Cancer Epidemiology and Health Services Research Group, Centre for Public Health, School of Medicine, Dentistry and Biomedical Sciences, Queen's University Belfast, Belfast, Northern Ireland

${ }^{5}$ Centre for Medical Education, School of Medicine, Dentistry and Biomedical Sciences, Queen's University Belfast, Northern Ireland; Belfast Health and Social Care Trust, Northern Ireland

${ }^{6}$ Centre for Cancer Research and Cell Biology, School of Medicine, Dentistry and Biomedical Sciences, Queen's University Belfast, Northern Ireland; Northern Ireland Biobank

\section{BACKGROUND}

Providing high quality care for dying patients and their families has been highlighted as a national priority in the United Kingdom $(\mathrm{UK})^{1}$ with national guidelines and policies existing to provide direction specific to the provision of end-of-life care (EOLC). These include National Institute for Health and Care Excellence 'Guidance for end-of-life care in adults'. ${ }^{2}$ and 'Endof-life Care Strategy: Promoting high quality care for adults at the end of their life' from the Department of Health. ${ }^{3}$ The challenges faced by dying patients are substantial and potentially overwhelming ${ }^{4}$ and those near the end-of-life may experience perhaps extreme symptoms that include physical, spiritual and psychosocial suffering. ${ }^{5}$ It is recognised that quality EOLC can only be delivered when the needs of both patients and their support network, such as families, are addressed; taking into account their priorities, preferences and wishes. ${ }^{6}$

Despite the inevitability of death, patients and families may not always receive the quality EOLC they desire. Patients and their families have reported sub-optimal EOLC with unmet needs in areas such as communication and information giving, ${ }^{7}$ and symptom control and emotional support. ${ }^{8}$ This can be exemplified in the case of the care of patients with cancer cachexia at end-of-life, where research uncovered a lack of communication and information giving from healthcare professionals about the causes and impact of cachexia in advanced cancer. ${ }^{9}$ They reported that this left patients and their families feeling apprehensive and distressed at an already emotive time, weakening their confidence in the ability of the staff to provide adequate care. In order to further investigate this response from healthcare professionals, Millar et al conducted a study exploring healthcare professionals' understanding and perception of cachexia at end-of-life. ${ }^{10}$ This revealed that a lack of understanding of this complex symptom at end-of-life contributed to a culture of avoidance, as staff struggled to recognise cachexia or understand how to manage it appropriately. Participants reported that an absence of professional education at both pre-registration and post-registration contributed to their lack of knowledge and understanding of cachexia at end-of-life and how to respond to it. ${ }^{11}$ 
This lack of preparation appears as a common thread throughout the literature, including at undergraduate level with evidence suggesting that end-of-life education is poorly delivered within undergraduate nursing and medical curricula. ${ }^{12,13}$ Medical students have reported feeling unprepared to deal with end-of-life issues ${ }^{14}$ and nursing students and newly qualified nurses report feeling ill-equipped to provide quality EOLC to patients and their families. ${ }^{1,15}$ It is a recognised area of concern for undergraduate students, with many reporting concerns about communication (such as talking about death and dying), how they will react to death and practical matters such as symptom management. ${ }^{16,17}$ This lack of preparation appears to have an impact in clinical practice. A recent independent investigation into the utilisation of the Liverpool Care Pathway ${ }^{18}$ highlighted a number of concerns about the competence of nursing and medical staff to care for the dying and bereaved. Too often there were variations and failings in the delivery of EOLC, causing unnecessary distress to people who were dying and those close to them. ${ }^{19}$

From the evidence presented above it is imperative that EOLC must have a predominant place in the curricula of undergraduate healthcare professionals, particularly in the disciplines of nursing and medicine, with effective teaching strategies tailored to the needs of the undergraduate learner.

\section{STRATEGIES FOR TEACHING END-OF-LIFE CARE}

Teaching strategies must provide meaningful connections between the student, course content, practical experience, and the dying patient. ${ }^{20}$ Literature on preferred teaching strategies for EOLC have been reported over the years, such as the preference for experiential approaches for teaching about death and dying. ${ }^{21}$ Experiential learning can aid the discovery of possibilities which may not be evident solely from direct experience. ${ }^{22}$ Experiential learning opportunities are necessary to allow students to spend time with dying patients and their families. ${ }^{23}$ For example, research has found that newly qualified doctors' competence and confidence in delivering care to patients at the end-of-life increased in tandem with accumulated exposure to EOLC. ${ }^{24}$

It has been argued that technological advances in healthcare have obscured the need for human compassion for those at the end-of-life and their families. Not surprisingly, public demand for a more holistic, integrated approach toward health, illness, death and dying has been increasing. ${ }^{25}$ The literature has reported on a number of different teaching strategies used to deliver EOLC, including:

'Traditional' classroom-based methods: EOLC education using 'traditional' teaching methods, such as didactic lectures, audiovisual aids and small group discussions in the classroom have been found to have had a positive impact on students' personal and professional development regarding care of the dying. ${ }^{26}$ Other 'traditional' classroom activity, such as seminars on EOLC, can help students to learn about communication skills, holistic care, and knowing what to expect in the final hours of life. ${ }^{27}$
Artistic strategies: Whilst 'traditional' teaching methods have had some previous positive evaluations as described, the use of theatre (a performance of Wit) has been reported as a more preferable teaching method of EOLC in comparison to didactic lectures and reading journal papers. ${ }^{28} \mathrm{~A}$ method known as 'storyboarding' — sharing stories through written words and pictures - is another artistic learning strategy and has been reported as a helpful way to learn how to identify cultural aspects and feelings related dying patients and valued by students as a way of sharing their experiences. ${ }^{29}$

Low and high fidelity simulation: Low fidelity simulation, using role-playing and low fidelity manikins, has been reported as useful by undergraduate nurses for developing communication skills for EOLC. ${ }^{30}$ High fidelity simulation using more sophisticated technology (such as computer controlled simulator manikins) has been reported as an effective way to change attitudes toward EOLC in undergraduate nursing and medical students. ${ }^{31}$

Online learning resources: Online EOLC education can include online courses. The use of an online learning course on death and dying found that students appreciated the ability to reflect on their experiences in a non-judgmental setting and online education increased their confident in EOLC. ${ }^{32}$ Other online resources include the use of virtual patient cases, which has been found to increase students' comfort and knowledge regarding EOLC. ${ }^{33}$

Clinical or voluntary placements: Aside from mandatory clinical practice placements forming part of students' healthcare programmes, (voluntary) placements specific to EOLC have been employed as a teaching strategy for EOLC education, such as visits to hospices. Such experiences can improve students' attitudes towards EOLC and students have reported improvements in self-perceived competence to care for dying patients following EOLC education placements. ${ }^{34}$

Standardised patients: Standardised patients (actors) have been used as a strategy to deliver EOLC education, and their use has been found to improve students' confidence and knowledge of EOLC. ${ }^{35}$ This strategy had also been reported to be a valuable way to practice conversations relating to death and dying before encountering patients at the end-of-life in clinical practice. ${ }^{36}$

Multimodal methods: Multimodal (or multidimensional) methods incorporate more than one type of teaching strategy into an EOLC curriculum or EOLC course. For example, 'traditional' methods such as didactic lectures partnered with experiential methods such as high fidelity simulation have been found to improve students' attitudes towards EOLC. ${ }^{37}$

Although, these studies have demonstrated the effectiveness of some of these teaching methods to deliver EOLC, there are a number of limitations within the published literature, which includes small-scale pilot studies with small samples sizes, potential bias, and the use of non-validated measurement tools for data analysis. Many of these studies were carried out in a uniprofessional context which recruited one type of student 
sample (such as nursing students only), or recruited students from a number of healthcare courses but the study did not focus on their learning in an interprofessional education (IPE) context.

A literature review by Gillan et al found that studies suggest end-of-life simulation to be a viable learning approach and have a positive impact on knowledge acquisition, communication skills, self-confidence, student satisfaction and level of engagement in learning. ${ }^{38}$ Simulation using high fidelity manikins is being increasingly used by educators in EOLC education, due to the lack of practice placements in this area due to increasing student numbers. ${ }^{31}$ Research conducted in the UK quantitatively evaluated the use of high fidelity simulation in EOLC education. ${ }^{31}$ This was a quasi-experimental, pre-test-post-test pilot study which recruited undergraduate students from nursing $(n=15)$ and medicine $(n=4)$. The intervention involved two independent simulation scenarios, intended to reflect the challenges of providing EOLC to dying patients and their families. A highfidelity simulation manikin was used as the patient and an actor played the role of the patient's relative. Using the Frommelt Attitudes Towards Care of the Dying (FATCOD) Form B-scale, results showed that students' attitudes towards EOLC were more positive after taking part in the simulation intervention in comparison with pre-intervention scores. This study noted that whilst high fidelity simulation is a viable method for teaching EOLC, the use of high fidelity simulators to teach EOLC in both undergraduate nursing and medical education in an interprofessional context is scarce. IPE, “...occurs when students from two or more professions learn about, from and with each other to enable effective collaboration and improve health outcomes ". ${ }^{39}$ After almost fifty years of enquiry, evidence sufficiently indicates that effective IPE enables effective collaborative practice, ${ }^{39}$ with the implementation of IPE into healthcare profession programmes gaining support from the worldwide governments and universities. ${ }^{40}$

\section{FUTURE RESEARCH}

A systematic review of the literature is being conducted to identify empirical evidence regarding teaching strategies which are effective for delivering EOLC education in undergraduate healthcare programmes. As there is a lack of evidence concerning the use of high fidelity simulation for teaching EOLC to undergraduate students for IPE, a study is currently being conducted as a part of the lead author's doctoral research training to address this gap in the literature. The study is currently recruiting undergraduate nursing and medical students to take part in high fidelity simulation scenarios (adaptations of those used in previous research). ${ }^{31}$ The study will employ a three-phase mixed-methods research design. Symbolic interactionism ${ }^{41}$ was the chosen theoretical framework for this study as it provides a meaningful framework by which to interpret and understand human behaviour and social interaction. This is relevant as the study is focusing specifically on IPE.

\section{THE WAY FORWARD}

EOLC is an internationally applicable area of healthcare. The research team has recognised this and has therefore made tentative links with a higher academic institution in Canada that is highly involved with undergraduate EOLC education with an IPE presence within the university. It is then hoped to develop a research agenda related to EOLC education that is globally applicable.

\section{CONFLICTS OF INTEREST}

The authors declare that they have no conflicts of interest.

\section{REFERENCES}

1. Cavaye J, Watts JH. End-of-life education in the pre-registration nursing curriculum. J Res Nurs. 2010; 17(4): 317-326.

2. National Institute for Health and Care Excellence (2017) Endof-life care for adults. Web site. https://www.nice.org.uk/guidance/qs13/chapter/Introduction-and-overview. Accessed March 292017.

3. Department of Health. End-of-life Care Strategy: Promoting High Quality Care for All Adults at the End-of-life. London: Department of Health; 2008.

4. Woo JA, Maytal G, Stern TA. Clinical challenges to the delivery of end-of-life care. Prim Care Companion J Clin Psychiatry. 2006; 8(6): 367-372.

5. Rome RB, Luminais HH, Bourgeois DA, Blais CM. The role of palliative care at the end-of-life. Ochsner J. 2011 11(4): 348352.

6. National Palliative and End-of-life Care Partnership. Ambitions for Palliative and End-of-life Care. A national framework for local action 2015-2020. 2015. Web site. http://endoflifecareambitions.org.uk/wp-content/uploads/2015/09/Ambitionsfor-Palliative-and-End-of-Life-Care.pdf. Accessed April 42017.

7. Reid J, McKenna H, Fitzsimmons D, McCance T. The experience of cancer cachexia: A qualitative study of advanced cancer patients and their family members. Int J Nurs Stud. 2009; 46(5): 606-616. doi: 10.1016/j.ijnurstu.2008.10.012

8. Gallagher R, Krawczyk M. Family members' perceptions of end-of-life care across diverse locations of care', BMC Palliative Care. 2013; 12: 25. doi: 10.1186/1472-684X-12-25

9. Reid J, McKenna H, Fitzsimmons D, McCance T. Living with cancer cachexia: Exploring the perspectives of patients and their significant others. Palliative Medicine. 2008; 22(4): 595-596. 
10. Millar C, Reid J, Porter S. Healthcare professionals' response to cachexia in advanced cancer: A qualitative study. Oncol Nurs Forum. 2013; 40(6): 393-402. doi: 10.1188/13.ONF.E393-E402

11. Porter S, Millar C, Reid J. Cancer cachexia care: The contribution of qualitative research to evidence based practice. Cancer Nursing. 2012; 35(6): 30-38. doi: 10.1097/NCC. 0b013e31823d52b7

12. Dickson GE, Clark D, Sque M. Palliative care and end-oflife issues in UK pre-registration, undergraduate programmes. Nurse Education Today. 2008; 28(2): 163-170. doi: 10.1016/j. nedt.2007.03.008

13. European Association for Palliative Care. Curriculum in Palliative Care for Undergraduate Medical Education. Milan, Italy: EAPC Taskforce; 2007.

14. Bowden J, Dempsey K, Boyd K, Fallon M, Murray SA. Are newly qualified doctors prepared to provide supportive and endof-life care? A survey of Foundation Year 1 doctors and consultants. J R Coll Physicians Edinb. 2013; 43(1): 24-28. doi: 10.4997/JRCPE.2013.105

15. Hopkinson JB, Hallett CE, Luker KA. Everyday death: How do nurses cope with caring for dying people in hospital? Int J Nurs Stud. 2005; 42(2): 125-133. doi: 10.1016/j.ijnurstu.2004.06.004

16. Cooper J, Barnett M. Aspects of caring for dying patients which cause anxiety to first year student nurses. Int $J$ Palliat Nurs. 2005; 11(8): 423-430. doi: 10.12968/ijpn.2005.11.8.19611

17. Edo-Gual M, Tomas-Sabado J, Bardallo-Porras D, MonforteRoyo C. The impact of death and dying on nursing students: An explanatory model. J Clin Nurs. 2014; 23(23-24): 3501-3512. doi: 10.1111/jocn.12602

18. Neuberger J, Gurthie C, Aaronovitch D, et al. More care, less pathway: A review of the Liverpool Care Pathway. 2013 Web site. https:/www.gov.uk/government/uploads/system/uploads/ attachment_data/file/212450/Liverpool_Care_Pathway.pdf. Accessed April 4, 2017.

19. Leadership Alliance for Care of the Dying. One Chance to Get It Right. 2014. Web site. https:/www.gov.uk/government/ uploads/system/uploads/attachment_data/file/323188/One chance_to_get_it_right.pdf. Accessed April 4, 2017.

20. Hold JL, Blake BJ, Ward EN. Perceptions and experiences of nursing students enrolled in a palliative and end-of-life nursing elective: A qualitative study. Nurse Educ Today. 2015; 35(6): 777-781. doi: 10.1016/j.nedt.2015.02.011

21. Irvine B. Teaching palliative nursing to students. Nursing Standard. 1993; 7(50): 37-39. doi: 10.7748/ns.7.50.37.s44
22. McGill I, Weil SW. Continuing the dialogue: New possibilities for experiential learning. In: Weil SW, McGill I, eds. Making Sense of Experiential Learning: Diversity in Theory and Practice. Milton Keynes, England: Society for Research into Higher Education and Open University Press; 1989: 245-272.

23. Kwekkeboom KL, Vahl C, Eland J. Impact of a volunteer companion program on nursing students knowledge and concerns related to palliative care. J Palliat Med. 2004; 9(1): 90-99. doi: 10.1089/jpm.2006.9.90

24. Anderson WG, Williams JE, Bost JE, Bernard D. Exposure to death is associated with positive attitudes and higher knowledge about end-of-life care in graduating medical students. J Palliat Med. 2008; 11(9): 1227-1233. doi: 10.1089/jpm.2008.0058

25. Singer PA, Bowman KW. Quality end-of-life care: A global perspective. BMC Palliative Care. 2002; 1(4): 1-10. doi: 10.1186/1472-684X-1-4

26. Ballesteros M, Centeno C, Arantzamendi M. A qualitative exploratory study of nursing students' assessment of the contribution of palliative care learning. Nurse Educ Today. 2014; 34(6): 1-6. doi: 10.1016/j.nedt.2013.12.010

27. Jackson MJ, Motley CL. End-of-life educational seminar in a prelicensure bachelor of science in nursing program. J Hosp Palliat Nurs. 2014; 16(6): 348-354. doi: 10.1097/ NJH.0000000000000070

28. Deloney LA, Graham CJ. Wit: Using drama to teach firstyear medical students about empathy and compassion. Teach Learn Med. 2003; 15(4): 247-251. doi: 10.1207/S15328015TL M1504_06

29. Lillyman S, Gutteridge R, Berridge P. Using a storyboarding technique in the classroom to address end-of-life experiences in practice and engage student nurses in deeper reflection. Nurse Educ Pract. 2011; 11(3): 179-185. doi: 10.1016/j. nepr.2010.08.006

30. Sarabia-Cobo CM, Alconero-Camarero AR, Lavin-Alconero L, Ibanez-Rementeria I. Assessment of a learning intervention in palliative care based on clinical simulations for nursing students. Nurse Educ Today. 2016; 45: 219-224. doi: 10.1016/j. nedt.2016.08.014

31. Lewis C, Reid J, McLemon Z, Ingham R, Traynor M. The impact of a simulated intervention on attitudes of undergraduate nursing and medical students towards end-of-life care provision. BMC Palliative Care. 2016; 15(67): 1-6. doi: 10.1186/s12904016-0143-2

32. Loerzel VW, Conner N. Advances and challenges: Student reflections from an online death and dying course. Am J Hosp Palliat Care. 2016; 33(1): 8-15. doi: 10.1177/1049909114549182 
33. Tan A, Ross SP, Duerksen K. Death is not always a failure: Outcomes from implementing an online virtual patient clinical case in palliative care for family medicine clerkship. Med Educ Online. 2013; 18. doi: 10.3402/meo.v18i0.22711

34. Gilliland I. Effects of a community-based hospice experience on attitudes and self-perceived competencies of baccalaureate senior nursing students. J Nurs Educ. 2015; 54(6): 335338. doi: 10.3928/01484834-20150515-04

35. Fink M, Linnard-Palmer L, Ganley B, Catolico O, Phillips W. Evaluating the use of standardized patients in teaching spiritual care at the end-of-life. Clin Simul Nurs. 2014; 10(11): 559566. doi: 10.1016/j.ecns.2014.09.003

36. Tchorz KM, Binder SB, White MT, et al. Palliative and endof-life care training during the surgical clerkship. J Surg Res. 2013; 185(1): 97-101. doi: 10.1016/j.jss.2013.05.102

37. Carman MJ, Sloane R, Molloy M, Flint E, Phillips B. Im- plementation of a learning bundle to promote end-of-life education for prelicensure nursing students. J Hosp Palliat Nurs. 2016; 18(4): 356-363. doi: 10.1097/NJH.0000000000000258

38. Gillan PC, Jeong S, van der Riet PJ. End-of-life care simulation: A review of the literature. Nurse Educ Today. 2014; 34(5): 766-774. doi: 10.1016/j.nedt.2013.10.005

39. World Health Organisation. Framework for Action on Interprofessional Education \& Collaborative Practice, Geneva: World Health Organisation; 2010

40. Coster S, Norman I, Murrells T, et al. Interprofessional attitudes amongst undergraduate students in the health professions: A longitudinal questionnaire survey. Int J Nurs Stud. 2008; 45(11): 1667-1681. doi: 10.1016/j.ijnurstu.2008.02.008

41. Blumer H. Symbolic Interactionism: Perspective and Method California. California, USA: University of California Press; 1969. 